Article

\title{
Seemingly Connected, Obviously Separate: The Parallel Realities of the UN Global Compact and the Multilateral Regimes in Water Governance
}

\author{
Gor Samvel \\ International Law Department, Graduate Institute of International and Development Studies, \\ Geneva-14456, Switzerland; gor.movsisyan@graduateinstitute.ch
}

Received: 21 July 2018; Accepted: 29 October 2018; Published: 5 November 2018

check for updates

\begin{abstract}
The UN Global Compact, being an institutional innovation in global governance, invites businesses to voluntarily commit to a selection of principles, rooted in multilateral regimes. Such commitment is expected to improve business practices and by that to close gaps in global governance. This spawns an expectation that through UN Global Compact business and multilateral treaty regimes will engage in mutually fertilizing and potentially coherent interaction to overcome the shortfalls of global governance. The current paper looks into this alleged interaction in the field of water stewardship and access to water. It explores first, the conceptual interdependence of the UN Global Compact and multilateral regimes in the respective fields and second, the ways in which the business practices reported under the UN Global Compact contribute to the advancement of the rules and principles thereof. The paper finds that the traditional multilateral systems and the innovative governance platform share an identical conceptual narrative but exist as separate realities on operational level. From the latter perspective the UN Global Compact might risk deepening governance gaps rather than close them.
\end{abstract}

Keywords: Global Compact; United Nations; non-state actors; water governance; human right to water; international water law; international water governance; international regimes; human rights obligations of private actors; business and human rights

\section{Introduction}

It is in the democratic deficit, legitimacy crises (Bäckstrand 2006) and in the failure of the United Nations (UN) multilateral regimes to account for more meaningful involvement of non-state actors (Kell 2005), that such innovation of global governance as the United Nations Global Compact (UN Global Compact) took its roots.

The UN Global Compact is framed as a corporate citizenship initiative which invites private economic entities to voluntarily commit to a selection of principles, rooted in multilateral regimes of international governance (Kell and Ruggie 1999; Drache 2001). Such commitment is expected to improve business practices that at times have been disruptive to the values sought after by some multilateral regimes.

Today, the UN Global Compact is a learning platform under the auspices of the UN that differs from the UN state-centric multilateral regimes in actors, in process and in output. For these reasons too, the creation of the UN Global Compact spawns an expectation that through the UN Global Compact businesses and multilateral treaty regimes will engage in mutually fertilizing and potentially coherent interaction to overcome the shortfalls of global governance not resolved by state-centric multilateralism. Should we, though, have such an expectation?

This paper aims to analyze: first, the conceptual interdependence of the UN Global Compact and multilateral regimes in the field of water stewardship and access to water and second, the ways in 
which the business practices reported under the UN Global Compact contribute to the advancement of the rules and principles of respective multilateral regimes. These observations should inform us broadly about whether respective multilateral regimes and UN Global Compact engage in the alleged interaction on both conceptual and empirical levels.

The theoretical-conceptual aspiration of this paper is to inform the academic debate on institutional change and non-state actors as to if and in what ways traditional multilateralism and its innovations enter in dialogue to fulfill outstanding objectives of global governance.

The structure of the paper proceeds as follows. The first part defines the theoretical objectives, followed by a second part which gives a historical overview of the UN Global Compact. The third and fourth sections explore respectively the conceptual interdependence between the UN Global Compact and the UN state-centric regimes and empirical observation about how the business contributes to the advancement of the rules of multilateral regimes in the domains of water stewardship and access to water. In the last part of the paper, drawing on the findings of the previous sections, I will attempt to speculate over the question of whether the institutional innovation of UN Global Compact as it stands today in relation to multilateral regimes does carry a potential of covering various governance gaps.

It is noteworthy from the onset that this paper does not seek to make normative statements, including policy recommendations, concerning UN Global Compact or multilateral regimes. It has no purpose also to compare them and to develop any argument concerning their further unity or disarray.

\section{Conceptual Framework}

The theoretical-conceptual aspiration of this paper comes from the dynamic organizational theory of change developed by Lilian Andonova in her recent book: "Governance Entrepreneurs: International organizations and the rise of Global Public-Private Partnerships" (Andonova). In it she challenges the apparent dichotomy of state-centric (change is driven by states as the main principle of international relations) and bureaucracy-focused (bureaucracy can pick from a pool of existing solutions leading to institutional adaptation rather than innovation or change) perspectives on change and stagnation of international institutions (Andonova, pp. 34-35). In her view:

"International organizations, under conditions of external turbulence and facilitated by their agency autonomy and expertise, have played a central role as both entrepreneurs and brokers of partnerships through supportive alliances". (Andonova, p. 36)

A case in point is also the UN Global Compact as a governance innovation established by then UN Secretary General Kofi Annan (Andonova, pp. 67-70).

This paper, though, only seeks to inform the academic debate on institutional innovation and change (i.e., Abbott et al. 2016; Abbott and Snidal 2010), about the ways this innovation enters in dialogue with already functioning multilateral regimes to bring about the desired changes in governance.

If the institutional changes are there to address deficiencies of multilateral regimes for better governance, then it becomes essential to enquire into the positioning of such innovations within the already functioning multilateral regimes (mutual reshaping and evolution of new features) and into the ways such changes contribute to achieving the objectives of multilateral regimes. In this two-step enquiry into institutional change, the assumption I make is the meaningful interaction of the two realities-state-centric traditionalism and private-centric innovation.

Next, the paper proceeds to the mentioned two steps of enquiry and only in the last part of it are the findings generalized in light of the respective academic debates.

\section{The UN Global Compact as an Innovation}

It was at the World Economic Forum in Davos, Switzerland in 1999 that the former UN Secretary General Kofi Annan proposed the Global Compact-a corporate citizenship initiative for advancing the objective of the United Nations (More on the origins of the Global Compact see in Kell 2003). 
According to close associates, Annan viewed collaboration with the private sector as an important and insufficiently-explored mechanism to advance the objectives of the UN: such partnerships were to be one of his legacies as Secretary-General. ${ }^{1}$

The text analysis of the speech ${ }^{2}$ in Davos suggests a careful crafting of a normative framework to justify collaboration between the private sector and the UN and to situate it within the agency authority of the organization (Andonova, p. 89). In his speech, Kofi Annan also indicated that:

"Globalization is a fact of life but I believe we have underestimated its fragility. The problem is this. The spread of markets outpaces the ability of societies and their political systems to adjust to them, let alone to guide the course they take."

Eventually, he called on individual business firms and their associations to embrace, support and enact a set of core values in the areas of human rights, labor standards and environmental practices ${ }^{3}$.

The Secretary-General's speech received an overwhelming response, both supportive (Kell 2005, p. 36) and skeptical (Andonova, pp. 93-95). In July 2000, the Office of Secretary General established the UN Global Compact with forty signatories, without the UN General Assembly involvement and through a process where government support played no essential role (Andonova, p. 93).

Quite minimalist and straightforward in objectives it is still challenging to conceive ${ }^{4}$ of the UN Global Compact in the traditional terms of state-centric global governance. What has been majorly emphasized by John Ruggie with respect to this initiative was that the Compact is not a code of conduct but instead a learning model.

In the words of its founders the UN Global Compact is a corporate citizenship initiative (Rasche and Kell 2010) to address the disconnect ${ }^{5}$ that emerged between the global network of production and finance and the overall system of institutional relations (Kell and Ruggie 1999, p. 101). Clearly, the initiative carries a significant message: the utmost necessity of more innovative involvement of non-state actors in global governance to close its various gaps by "... going beyond legal requirements and filling the regulatory vacuum" (Scherer and Palazzo 2011).

\section{The Parallel Realities}

In this part of the paper I observe the conceptual interdependences, if any, between the multilateral treaty regimes and the UN Global Compact in the fields of water stewardship and access to water. I do so by selectively looking into those features of both state-centric regimes and private-centric platforms, which point to mutual relevance and reinforcement.

1 Interviews with John Ruggie, former Assistant Secretary-General for Strategic Planning, February 2008, Cambridge, MA and discussion with Kemal Dervis, former Administrator of UNDP, March, 2010, Geneva. See in Andonova 2017, p. 70.

2 United Nations Press Release SG/SM/6881: Secretary-General Proposes Global Compact on Human Rights, Labour, Environment. In Address to World Economic Forum in Davos. Available online: https:/ / www.un.org/press/en/1999/ 19990201.sgsm6881.html (accessed on 1 November 2018).

3 United Nations Press Release SG/SM/6881: Secretary-General Proposes Global Compact on Human Rights, Labour, Environment. In Address to World Economic Forum in Davos. Available online: https://www.un.org/press/en/1999/ 19990201.sgsm6881.html (accessed on 1 November 2018).

4 Perhaps it is for this reason that the authors use variety of terms and concepts to define the UN Global Compact: (1) "umbrella organization supporting corporate good conduct" (Lau et al. 2017); (2) "a small step bridging the imbalance between the economic globalization and governance "initiative to increase and to diffuse the benefits of global economic development", see in Williams 2007); (3) "a new governance arrangement offering a platform" (Rasche et al.) These are but a non-exhaustive list of definitions applied to describe and define the UN Global Compact.

5 Such disconnect in its turn is explained by "... three negative attributes of the recent era of global market integration: (1) unequal distribution of benefits, (2) growing imbalance in global rule making, (3) greater vulnerability to unfamiliar and unpredictable forces": see in (Ruggie 2008). 


\subsection{Water Stewardship and Access to Water under the UN Global Compact}

For businesses, joining the UN Global Compact means committing to its 10 principles $^{6}$ in the areas of human rights, labor, environment and anti-corruption which are derived from: (1) the Universal Declaration of Human Rights,; (2) the International Labor Organization's Declaration on Fundamental Principles and Rights at Work; ${ }^{8}$ (3) the United Nations Convention Against Corruption ${ }^{9}$; and (4) the Rio Declaration on Environment and Development. ${ }^{10}$

According to the founders of the UN Global Compact " ... the areas and the principles chosen are the most relevant at the corporate level and at the global rule-making level while at the same time rooted in solid international commitments and even treaty obligations" (Kell and Ruggie 1999, p. 323). Seeing the roots of institutional innovations of global governance in the treaty obligations is an observable tendency in private-centric initiatives, evidenced also by Principle 12 of the United Nations Guiding Principles on Business and Human Rights (UNGPs) ${ }^{11}$ which states that the responsibility of business enterprises to respect human rights refers to internationally recognized human rights. ${ }^{12}$

The UN Global Compact also introduces focus areas, including the area on "Environment" which is tied to Principles 7 (support a precautionary approach to environmental challenges), 8 (promote greater environmental responsibility) and 9 (encourage development and diffusion of environmentally friendly technologies). The environment focus area covers such topics as climate change, water and sanitation, as well food and agriculture. The cluster on water and sanitation integrates the Water Action Hub (promotes collaboration among groups of companies and/or other stakeholders), the CEO Water Mandate (helps companies to develop, implement and disclose water sustainability policies and practices) and the Water Stewardship (assesses the company's position on its water management path and charts a course of actions for the future). ${ }^{13}$

To direct business actors, the UN Global Compact has developed various guiding materials. ${ }^{14}$ These materials help companies adopt an internationally recognized human rights lens or methods of water stewardship to improve their activities. For example, the "Guidance on Respecting Human Rights to Water and Sanitation: Bringing a Human Rights Lens to Corporate Water Stewardship," sets out key steps for the successful adoption of a human rights approach in the corporate management of water resources. ${ }^{15}$

Beyond showcasing the progressive corporate commitments, the UN Global Compact exhibits limited capacity to guide private actors in their efforts to operationalize its general principles into a business practice in question. While providing deeper insights, the guiding materials are general in their discussions of corporate practices and rely more on the core international commitments and

6 Out of these 10 principles five- the 1st, 2nd, 7th, 8th and 9th-appear to be the most relevant for the purposes of this paper: 1. support and respect internationally proclaimed human rights (Principle 1); 2 . not to be complicit in human rights abuses (Principle 2); 3. support a precautionary approach to environmental challenges (Principle 7); 4 . promote greater environmental responsibility (Principle 8); and 5. encourage development and diffusion of environmentally friendly technologies (Principle 9). Available online: https://www.unglobalcompact.org/what-is-gc/our-work/ (accessed on 1 November 2018).

7 Available online: http://www.un.org/en/universal-declaration-human-rights/ (accessed on 1 November 2018).

8 Available online: http://www.ilo.org/declaration/lang--en/index.htm (accessed on 1 November 2018).

9 Available online: https://www.unglobalcompact.org/what-is-gc/mission/principles (accessed on 1 November 2018).

10 Available online: http://www.un.org/documents/ga/conf151/aconf15126-1annex1.htm (accessed on 1 November 2018).

11 UNGPs have been developed by John Ruggie and have been unanimously adopted by the Human Rights Council.

12 "The responsibility of business enterprises to respect human rights refers to internationally recognized human rights-understood, at a minimum, as those expressed in the International Bill of Human Rights and the principles concerning fundamental rights set out in the International Labour Organization's Declaration on Fundamental Principles and Rights at Work." For more on the process of adoption of Guiding Principles see in (Aaronson and Higham 2013)

13 Available online: https://www.unglobalcompact.org/what-is-gc/our-work/environment/water (accessed on 1 November 2018).

14 See, for example, (The CEO Water Mandate 2014; The CEO Water Mandate 2015).

15 The CEO Water Mandate 2015. 
treaty obligations. ${ }^{16}$ Effectively, the UN Global Compact reformulates international law standards on the human right to water and water management into a language that speaks to corporate needs.

In the following sub-section I turn to the multilateral regimes on water governance and the human right to water with the reverse objective of exploring the relevance of these regimes for private actors.

\subsection{Water Stewardship and Access to Water under the UN State-Centric Regime}

There are multiple ways in which one can sketch international regimes on water governance. They can be defined strictly-as conventional cooperative arrangements only on water resources (Conca 2006), or loosely-as multilateral arrangements on environment that, among other things, assist with the protection of water resources (Boisson de Chazournes et al. 2011). This paper discusses international water governance regimes in their strict sense.

The emergence of community interest in the protection of water resources dates to the 1911 Madrid Declaration of the Institute of International Law. The response of the nations to the emerging community of interest ${ }^{17}$ has been through the three main international treaties: the UNECE Water Convention on the Protection and Use of Transboundary Watercourses and International Lakes ${ }^{18}$ (Water Convention) and its Protocol on Water and Health ${ }^{19}$ and the UN Convention on the Law of the Non-Navigational Uses of International Watercourses ${ }^{20}$ (Watercourse Convention). "While the focus of the 1992 Water Convention is the protection of international watercourses from the harm linked to their equitable and reasonable use, the focus of the 1997 Convention is the equitable and reasonable use of international watercourses linked to their protection from pollution (Fisher 2009). The "groundnorm" for both is " ... equitable and reasonable utilization linked to the prevention of pollution and the protection of the environment."21

The interstate institutional arrangements ${ }^{22}$ for governance of water resources vary greatly. They include international organizations, such as the UN Economic Commission for Europe and the UN Economic Commission for Latin America and the Caribbean, as well as joint commissions like the International Commission for the Protection of the Rhine, the International Commission for the Protection of the Danube River or International Boundary and Water Commission on the Colorado and Rio Grande Rivers and so forth.

The Water Convention provisions cover a variety of measures on prevention of harm and quality control, methods of assessing environmentally sound technologies, information exchange, research, development and so forth. ${ }^{23}$ The substance of the 1997 Watercourses Convention deals predominantly with the reasonable and equitable utilization of international watercourses; the prevention of causing significant harm; and various tools of prevention, reduction and control of pollution. ${ }^{24}$

16 See, for example, in "Part II Key Resources" of Ibid., pp. 91-95.

17 The term "community of interest" as an international water law category was coined by the Permanent Court of International Justice in the case "Territorial Jurisdiction of Int'l Comm'n of River Oder (U.K. v. Pol.), 1929 P.C.I.J. (Ser. A) No. 23 (Sept. 10)".

18 UNECE Convention on the Protection and Use of Transboundary Watercourses and International Lakes, Helsinki, 17 March 1992, United Nations Treaty Series, Vol. 1936, p. 269.

19 Protocol on Water and Health to the 1992 Convention on the Protection and Use of Transboundary Watercourses and International Lakes, London, 17 June, 1999, United Nations Treaty Series, Vol. 2331, p. 202.

20 UN Convention on the Law of the Non-Navigational Uses of International Watercourses, Doc. A/51/869. C.N. 353.2008.TREATIES-1 of 6 May 2008, New York, 21 May 1997.

21 Ibid., p. 125.

22 See more on these arrangements in (Caponera 1985, 2003).

23 The measures included in the Convention are: "(i) prevention of emissions and waste-water discharges; (ii) control of the quality, (iii) biological treatment and equivalent processes; (iv) reduction of nutrient inputs; (v) sustainable water resource management; (vi) programs of monitoring; (vii) research into and development of effective technologies, specific research programs aimed at methods for the assessmentof environmentally sound technologies, phasing out substances likely having transboundary impact; (viii) exchange of information on issues covered by the Convention; (ix) elaborated rules, criteria and procedures on the field of responsibility and liability; and (x) maintenance of industrial and commercial secrecy.In addition, the Water Convention envisages special arrangements between the riparian Parties, such as establishment of joint bodies, consultations between riparian states and joint warning and alarming systems."

24 The main measures included in the Convention are: "(i) equitable and reasonable utilization of international watercourses, factors defining such utilization; (ii) utilization in a way not to cause significant harm to all watercourse states, when 
Even a strict textual reading of the Water Convention or the Watercourses Convention leaves me with the understanding that some of their provisions create obligations, the fulfilment of which, at minimum, depends on private actors. A number of treaty provisions of the Water Convention, for example, encourage: (1) prevention, control and reduction of transboundary impact by taking such measures as the application of best available technologies (Article 3.1); (2) consideration of existing lists of industrial sectors or industries and of such hazardous substances in international conventions or regulations, which are applicable in the area covered by the Convention (Article 3.2); (3) protection of information related to industrial and commercial secrecy (Article 8); and (4) exchange of best available technology, particularly through the promotion of the commercial exchange of available technology and of direct industrial contacts and cooperation, including joint ventures (Article 13.4).

Mostly because of the state-centric narrative of international water governance there is limited knowledge about the duties that treaty obligations create for private actors in the field of water protection and use. Perhaps such duties are more evident with respect to the human right to water.

In November 2002, the United Nations Committee on Economic, Social and Cultural Rights (CESCR) adopted General Comment No. 15 on the human right to water and sanitation. By referring to the legal foundations of the right to water, CESCR concludes;

"Article 11, paragraph 1, of the Covenant specifies a number of rights emanating from and indispensable for, the realization of the right to an adequate standard of living including adequate food, clothing and housing. The right to water clearly falls within the category of guarantees essential for securing an adequate standard of living, particularly since it is one of the most fundamental conditions for survival." 25

The right to water also derives from the right to health entrenched in Article 12 of the Covenant. ${ }^{26}$ By recognizing the right to water as an indispensable part of the right to adequate standards of living, the General Comment identified three key characteristics of its normative content: (a) Availability, ${ }^{27}$ (b) Quality ${ }^{28}$ and (c) Accessibility. ${ }^{29}$

Following the recognition by the General Comment of the CESCR, on 28 July 2010, the United Nations General Assembly recognized the human right to water and sanitation in its Resolution $64 / 292^{30}$. It acknowledged that clean drinking water and sanitation are essential for the full enjoyment of life and all human rights. World Health Assembly Resolution 64/24 from May 2011 31 and the

caused to eliminate and mitigate such harm; (iii) regular cooperation, exchange of data and information; (iv) exchange of information of planned measures on the conditions of an international watercourse, provision of timely notification of planned measures; $(\mathrm{v})$ joint protection, preservation of the ecosystems of international watercourses; (vi) prevent, reduce and control pollution; (vii) consult to arrive at mutually agreeable measures and methods to prevent, reduce and control pollution; (viii) preventing introduction of species, alien or new into an international watercourse; (ix) means to protect and preserve the marine environment; $(x)$ planning the sustainable development of international water management; (xi) regulation of the flow of an international watercourse; and (xii) safe operation and maintenance of installations."

25 UN Committee on Economic, Social and Cultural Rights (CESCR), General Comment No. 15: The Right to Water (Arts. 11 and 12 of the Covenant), adopted 20 January 2003, (E/C.12/2002/11).

26 UN Office of the High Commissioner for Human Rights (OHCHR), Fact Sheet No. 35, The Right to Water, 2010, No. 35.

27 Water supply for each person must be sufficient and continuous for personal and domestic uses.

28 The water required for each personal or domestic use must be safe, therefore free from micro-organisms, chemical substances and radiological hazards that constitute a threat to a person's health. Furthermore, water should be of an acceptable colour, odour and taste for each personal or domestic use.

29 Water and water facilities and services must be accessible to everyone without discrimination, within the jurisdiction of the State party. Accessibility has three overlapping dimensions: (i) Physical accessibility: water and adequate water facilities and services, must be within safe physical reach for all sections of the population; (ii) economic accessibility: Water and water facilities and services, must be affordable for all, including the most vulnerable or marginalized sections of the population, in law and in fact, without discrimination on any of the prohibited grounds; and (iii) Information accessibility: accessibility includes the right to seek, receive and impart information concerning water issues (General Comment No. 15: The Right to Water (Arts. 11 and 12 of the Covenant), adopted 20 January 2003, (E/C.12/2002/11).

30 UN General Assembly Resolution 64/292 “The human right to water and sanitation”, adopted 28 July 2010 (A/64/L.63/Rev.1 and Add.1).

31 World Health Assembly Resolution 64/24 “Drinking-Water, Sanitation and Health”, adopted 24 May 2011 (A64/24). 
Human Rights Council Resolution 18/132 also recognize the right to water and call upon the water and sanitation sector to progressively achieve the full realization of the right to safe drinking water and sanitation for all. The human right to safe drinking water and sanitation continues to be affirmed by the UN Human Rights Council and continues to be observed, particularly by the Special Rapporteurs on the right to safe drinking water and sanitation. ${ }^{33}$

The World Bank report on the human right to water extends its normative content " . . beyond the provision of water for drinking purposes ... to water for environmental hygiene and health generally, as well as for growing food" (Salman and McInerney-Lankford 2004).

The impact of private actors on the full enjoyment of the right to water and sanitation is well documented. Business is widely engaged in water supply and water management practices. The World Bank lists more than 100 countries in Asia, Africa and Latin America where private companies play a major role in the provision of water supply and sanitation. ${ }^{34}$ The UN Office of the High Commissioner's Fact Sheet No 35 on "The right to water" also touches on the share of non-state actors in the responsibilities of securing access to water and sanitation. The fact sheet makes multiple references to the UN Global Compact, explaining that many corporations have made voluntary commitments to respect and support the human right to water, notably by signing up to the United Nations Global Compact and have developed their own human rights policies, programs and tools to incorporate them into their business operations. ${ }^{35}$

\subsection{The Points of Conceptual Interdependence}

To conclude this part of the paper, for now it suffices to state the evident: the UN Global Compact's conceptual frameworks on water and sanitation rely substantively on normative meanings and principles of the state-centric treaty regimes. This governance innovation attempts to forge environmental responsibility of private actors, including in the field of water and sanitation, by application of such fundamental principles as the principles of precaution, the principles of technological diffusion and respect for human rights, including the right to water. These principles are endogenous to the international water law system and the human right to water stands firmly next to the other internationally recognized human rights. Moreover, in its guiding materials for business the UN Global Compact makes extensive references to the language and the exigencies of the multilateral system.

On the other side are the substantive provisions of the Water Convention and the Watercourse Convention and the normative content of the right to water. The established obligations and entitlements address states but also speak through them to other actors who carry out activities that impact water resources, bear water scarcity associated risks and provide access to water.

Some ninety-two countries had embraced the liberalization of the water sector (Dellapenna and Gupta 2008), even though full privatization remains an exception in the sector (Ménard and Aleksandra 2011). This says a lot about the capacity-share within the national legal orders in meeting the needs of multilateral regimes. In other words, if a Party to the Water Convention, whose water resources are managed by private companies or even by state owned enterprises, attempts to implement the polluter pays principle (Article $2.5 \mathrm{~b}$ ), it has no other path but to transfer the cost internalization to the (semi)private sector. Next to this type of involvement, of direct concern for private actors is the water scarcity with varying risks for different sectors (food production, beverages, energy and so on).

32 Human Rights Council Resolution 18/1 "The human right to safe drinking water and sanitation", adopted 28 September 2011 (A/HRC/18/L.1).

33 The first mandate of the Special Rapporteur (Catarina Albuquerque, Portugal) was established in 2008 and was concluded in 2013. The last mandate commenced in November 2014 under Mr. Léo Heller from Brazil.

34 Water Aid Ethiopia. Tapping into private sector, Briefing note No. 7, p. 2.

35 UN Office of the High Commissioner for Human Rights (OHCHR), Fact Sheet No. 35, The Right to Water, 2010, No. 35. 


\section{The Empirics of the UN Global Compact and the Multilateral Regimes of Water Governance}

To explore if and how the business practices reported to the UN Global Compact reinforce the principles of multilateral regimes on water and sanitation, I undertook an empirical evaluation of the communications on progress (COP) submitted by companies to the UN Global Compact.

According to the UN Global Compact Policy on Communicating Progress, the COP is an annual disclosure through which a business informs its stakeholders about its efforts to implement the principles of the UN Global Compact. COPs can be submitted in any language. A failure to submit a COP results in a change of participant status and can eventually lead to the expulsion of a business from the initiative. To illustrate their progress as compared to the previous reporting period the companies are required to have a measurement of outcomes in the COP, which is a self-assessment of the degree to which their own targets or performance indicators were met, or other qualitative or quantitative measurements of results. ${ }^{36}$

\subsection{Methodology of Empirical Evaluations}

Considering the objectives of this paper, the empirical analysis encompasses three key directions: (1) the scope of the UN Global Compact's listed organizations that conduct water related business in selected sectors, (2) the activities of the businesses, with the aim of exploring the types of engagement in water stewardship and provision of drinking water; and (3) direct references to the international water law sources, if any.

The primary sources for the data set of this paper are COPs. The scope of data for analysis has been selected through the following analytical steps:

Firstly, a database of all the active profiles of the companies listed on the Global Compact web page was created by applying a data-mining program. ${ }^{37}$ The result was around 18,355 company-specific pages (not all these pages, though, contain communication reports of the companies for different reasons).

Secondly, a text analysis tool was developed that allowed me to filter the data by sector (i.e., Chemicals, Oil \& Gas, etc.). The algorithm of the keyword search displays the keyword-specific parts of the companies' communications on progress (reports) and the three sentences that precede and follow the sentence where the keyword was used. If the searched keyword appears in the previous or the next sentences, then the same logic of the text selection continues. The search was conducted in the most recent communications of progress of the companies to the UN Global Compact.

Out of six sectors of the UN Global Compact that in my view have potentially high impacts on water resources (Beverages, Food Producers, Industrial Metals \& Mining, Oil \& Gas Producers, Mining and Forestry \& Paper) I have selected three: (1) Production of Beverages, (2) Food Production and, (3) Mining. These sectors have been chosen for being relatively different domains of economic activity and for requiring varying degrees of water use.

In each sector, the application of the above-described search technique resulted in 120 progress reports overall: (1) Beverages—45,,$^{38}$ (2) Food production—62 39 and (3) Mining-13.40 The keyword "water" was applied and the reports submitted in languages other than English were not part of the result, with the exception of 5 reports where the English word "water" has simultaneously been used. This, of course, introduces a language bias in the dataset. Obviously, the number of companies

6 UN Global Compact Policy on Communicating Progress. As updated 1 March 2013.

37 Available online: https:/ / www.unglobalcompact.org/what-is-gc/participants (accessed on 1 November 2018).

38 The Global Compact web page displays 132 reports as of 6 June 2018. Out of 132 around 40 profiles contained no progress reports. Therefore, the result represents around $54 \%$ of the available reports.

39 The Global Compact web page displays 442 reports as of 6 June 2018. Out of 442 around 80 profiles contained no progress reports. Therefore the result represents around $19 \%$ of the available reports.

40 The Global Compact web page displays 50 reports as of 6 June 2018. Out of 50 around 8 profiles contained no progress reports. Therefore, the result represents around $31 \%$ of the available reports. 
reporting on water-related issues in the respective sectors is more than what the applied methodology permits me to identify. Nonetheless, the analyses of this paper are based on approximately $54 \%$ of reports from the beverage industry, $19 \%$ from the food production industry and 31\% from the mining industry. ${ }^{41}$

Once the parts of the reports were identified, a qualitative coding was conducted to obtain a systematic overview of the ways that businesses have been engaging in the management of water resources and the right to water and sanitation. The findings of the latter exercise were contrasted against the substantive provisions of the Water Convention and the normative characteristics of the right to water. The objective of this kind of contrasting was not to identify the direct normative references, though in some instances references to the right to water emerge. Rather, it has pursued to explore from a broader perspective whether the activities that the companies are engaged in fall under or relate to the Water Convention and the normative criteria of the right to water.

The qualitative results are contrasted only against the provisions of the Water Convention and what constitutes the normative basis of international recognition of the human right to water. I have chosen the UNECE water treaty framework because its scope, departing from the historically predominant transboundary approach (Moynihan 2018), is more ecosystem-orientated and thus is more relevant for the types of activities in which private actors might possibly be engaged.

\subsection{The Scope of Organizations}

\section{Geographic Distribution and Scale of the Companies}

In the beverage industry, out of 45 reporting enterprises identified, 11 were small and medium enterprises (SMEs) and 44 were companies (large enterprises). The majority of the reporting came from businesses operating in Europe and the least engaged were those from North America (See Chart 1 below). ${ }^{42}$ In the sector of food production, out of 62 reporting enterprises identified, 6 were SMEs and 56 were large enterprises. Much of the reporting came from businesses operating in Europe and the least involved were those in the Middle East (See the Chart 2 below).$^{43}$ And lastly, in the mining sector, out of 13 reporting enterprises identified, 1 was an SME and 12 were large enterprises. The majority of reporting companies were operating in Latin America (See the Chart 3 below). ${ }^{44}$

In the sample of 120 enterprises, the simple majority (64) operate in Europe.

Ten enterprises in the sample were expelled from the UN Global Compact because of failure to communicate their progress ${ }^{45}$ and five had voluntarily asked for withdrawal. ${ }^{46}$ In the face of low involvement of non-European businesses, it is particularly disquieting that the enterprises expelled or asking for withdrawal have been mostly non-European.

41 The percentage calculation is based on the overall number of companies listed on the Global Compact web page, excluding those who have not yet submitted their progress reports.

42 Among the reporting companies are: "Anheuser-Busch InBev NV"-Belgium, "Carlsberg Group"—Denmark, "Heineken N.V."-The Netherlands, "Pernod Ricard Italia"-Italy, "The Coca-Cola Company"-United States of America, "Unilever South Africa pty Ltd."-South Africa, "Bavaria S.A"-Colombia and others.

43 Among the reporting companies are: "Agricola Chapi S.A."-Peru, "Bonduelle"-France, "Campbell Soup Company"-United State of America, "Chocoladefabriken Lindt \& Sprungli AG"-Switzerland, "DKG GROUP"-Greece, "Michinoku Trading LLC"—Japan, "Finlay International Limited"—Bangladesh, "AMAGGI"—Brazil, "Hashem Brothers for Essential Oils and Aromatic Products"—Egypt, "Kelani Valley Plantations PLC"—Sri Lanka, "Shakarganj Mills Limited"-Pakistan and others.

44 Among the reporting companies are: "Anglogold Ashanti"—Colombia, "Goldcorp"—Canada, "Tata Chemicals Magadi Ltd."-Kenya, "PT Kaltim Prima Coal (KPC)"—Indonesia, "Sesa Goa Ltd."—India, “Aurico Gold Inc."—Mexico, "Teck Operaciones Mineras Chile Limitada"—Chile, "Hochschild Mining Plc." —Peru, "Glencore"—Switzerland.

45 "Coca-Cola Sabco Pty Ltd."- South Africa, "Produce World Ltd."-United Kingdom, "UAB Svyturys-Utenos Alus"-Lithuania, "Salsabil Co Inc."—Syrian Arab Republic, "Michinoku Trading LLC"—Japan, "Sun Food International Co., Ltd."-Thailand, "La Cabana Sugar Mill" - Colombia, "ASYA Fruit Juice and Food Industry Inc."—Turkey, "Jubilant Foodworks Limited"-India.

46 "S.V. Miguel Torres S.A."—Chile, “Agrokor d.d."—Croatia, “Nestle Dominicana S.A."—Dominican Republic, "Pulmuone Co., Ltd."-Republic of Korea. 


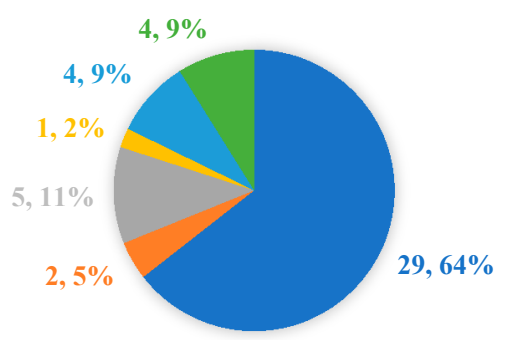

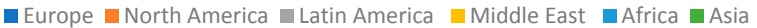

Chart 1. Geography of Reporting Businesses (Industry-Beverages).

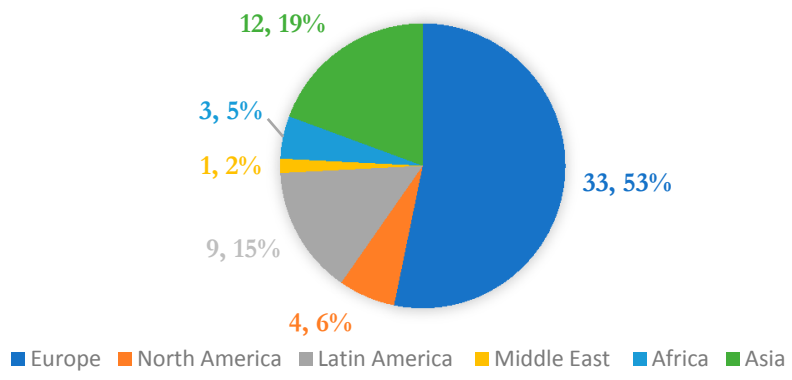

Chart 2. Geography of Reporting Businesses (Industry-Food Producers).

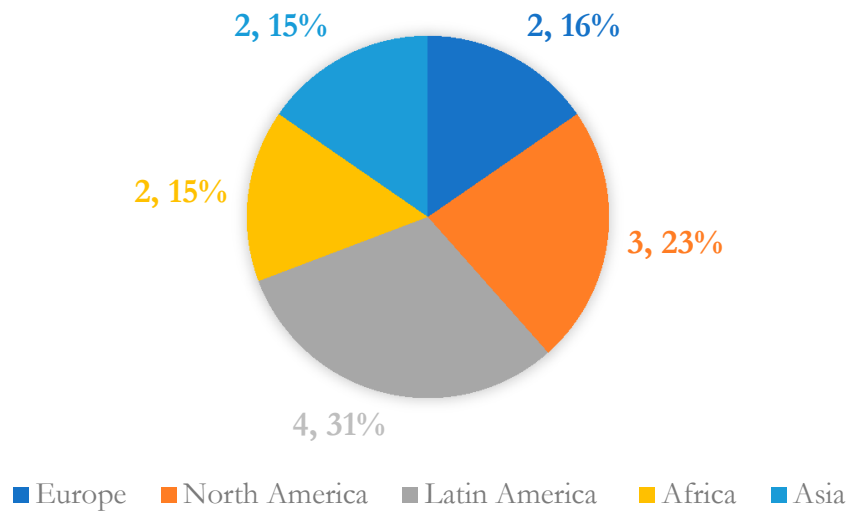

Chart 3. Geography of Reporting Businesses (Industry-Mining).

\subsection{Business in the Domains of Water Stewardships and Access to Water}

\subsubsection{Water Stewardship}

The practices that these companies reported in the field of water use and protection varies to a certain degree but boils down to an identical scope of actions. Across these three sectors, the water management strategies of businesses reportedly deal with the reduction of water consumption, improvement of water-related production efficiency, recycling of used water for its further reuse or release into the environment, wastewater treatment practices and reduction of the negative impacts of different practices on water resources and the environment. These management activities are carried out both within the production sites and throughout the supply chain, depending on the type of the activity.

As reported, businesses ensure advancement of the above practices by individual goal-setting (i.e., quantified targets for water consumption reduction), quantified representation of the pollutants released into the water, mapping of the water stressed areas, source vulnerability and water balancing 
analysis, reforestation, replenishments, ${ }^{47}$ infrastructure development, ${ }^{48}$ water metric data savings ${ }^{49}$ and so forth. For example, the Coca-Cola European Partners (CCEP-United Kingdom) reported on the decrease of groundwater withdrawal and thus the improvements of natural supply to the wetlands of the Tablas de Daimiel's Guadiana River (Spain). Arca Continental, S.A.B de C.V. (Mexico) reported on the reduction of industrial consumption and reuse, as well as on the objectives to reduce its water footprint by reaching 1.5 liters of water used for each liter of beverage produced by 2020, instead of the 1.71 liters used presently.

The juxtaposition of the results of my qualitative analyses indicates that the water management activities of businesses contribute to the improvement of state practice, at minimum by cutting of unsustainable usages of water (water usage economy), improvement of water quality, development of wastewater infrastructure and improving wastewater treatment, water recycling and so forth ${ }^{50}$. The reported activities are, by and large, relevant for Articles 3 and 5 of the Water Convention. The actions of companies, as reported, have been directed to reduce the emissions of pollutants (Article 3.1(a)), wastewater treatment and limiting of discharges (Article 3.1(b), (c)), application of best available technologies (Article 3.1(c), (f)), sustainable water management (Article 3(i)) and measures to prevent the pollution of groundwater (Article 3.1(k)). Research and development is also part and parcel of the water stewardship of the companies (Article 5).

\subsubsection{Right to Water and Sanitation and Reference to International Law}

Out of the 120 progress reports analyzed, in only $20^{51}$ was I able to trace down a discussion of questions regarding access to water and sanitation. Such engagement is either direct or takes the form of support for projects on access to water and sanitation. Most of the companies with direct involvement in the improvement of water provision and sanitation either operate in developing countries or in countries with emerging economies. This list includes Coca-Cola Icecek (Turkey) engaged in Pakistan; Coca-Cola Sabco Pty Ltd. (South Africa) engaged in Shri Lanka, Kenya and Tanzania; Mabroc Teas Pvt Ltd. (Sri Lank) engaged in Dutuwewa (Anuradhapura); and Hashem Brothers for Essential Oils and Aromatic Products (Egypt) engaged in Egypt. A small number of companies operating in developed countries were engaged in actions directed towards the improvement of water access in developing countries. $^{52}$

The UN Global Compact-listed companies are encouraged to refer to relevant international law sources and provisions that are reinforced by their practices. In their reports, the companies are silent about the international water law treaties and principles, in contrast to the explicit references to other international treaty regimes, for example labor conventions, human rights instruments and so on. ${ }^{53}$

47 The Coca Cola Company reports 115\% of replenishment goal achieved: Coca-Cola Sustainability update 2015/16, p. 7 .

48 I.e., water treatment plants (such activities are reported, for example, by "Coca-Cola HBC Slovenija d.o.o"-Slovenia, "Heineken N.V."-The Netherlands, "Arcus-Gruppen AS"—Norway, "Pesquera Diamante"—Peru, "Goldcorp"—Canada and others) or underground tankers (such activities are reported, for example, by "Chocoladefabriken Lindt \& Sprungli AG"-Switzerland).

49 I.e., "UAB Svyturys-Utenos Alus"-Lithuania.

50 Not in a strictly normative sense as explained in the part of this paper on the "Data collection methodology".

51 The reporting companies are: "Anheuser-Busch InBev NV"-Belgium, "Coca-Cola Icecek"-Turkey, "Coca-Cola Sabco Pty Ltd"—South Africa, "Arca Continental, S.A.B de C.V."-Mexico, "Fomento Economico Mexicano S.A. de C.V.-FEMSA"-Mexico, "Mabroc Teas Pvt Ltd."-Sri Lanka, "The Coca-Cola Company"-United States of America, "Unilever South Africa pty Ltd."—South Africa, "Bidco Africa Limited"—Kenya, "Chocoladefabriken Lindt \& Sprungli AG"-Switzerland, "Finlay International Limited"-Bangladesh, "Hashem Brothers for Essential Oils and Aromatic Products"-Egypt, "Monsanto Company"-United States of America, "Nestle S.A."-Switzerland, "PepsiCo, Inc."-United States of America, "Unilever"-United Kingdom, "SA San Miguel A.G.I.C.I. y F."-Argentina, "Anglogold Ashanti Colombia"-Colombia, "PT Kaltim Prima Coal (KPC)"-Indonesia, "Sesa Goa Ltd."-India.

52 The list includes, for example, (1) "Anheuser-Busch InBev NV"-Belgium, which in 2017 expanded its ambition to provide access to safe water to 3.5 million people in the developing world by 2020. "Chocoladefabriken Lindt\&Sprungli AG"-Switzerland, which as part of its farming program in Ghana, Ecuador and Madagascar does investments in providing access to clean drinking water and school refurbishment.

53 Among those sources were the UN Convention against Corruption (Recueil des Traités, 14 décembre 2005, vol. 2349, p. 41; (Doc. A/58/422), the core International Labour Organization conventions (i.e., 1979 UN Convention on the Elimination 
In the sample of 120 reports, around 35 companies had direct reference to both hard and soft sources of international law. Even direct references to international law sources may express a predominantly formalistic, rather than substantive, side of business engagement with international law, the absence of reference to multilateral sources, in my view, still indicates that there is a question of whether businesses see any direct connection between their actions and multilateral water regimes.

To conclude, it is apparent that the water stewardship activities reported by businesses claim to reduce water consumption and to mitigate impacts on water resources. Some companies (18 out of 120) are also involved in activities to improve access to water and sanitation. When contrasted to the substantive provisions of the Water Convention, the practices of the companies appear to contribute, at minimum, to prevention, control and reduction of transboundary impacts from various sources (Article 3), as well as to the research and development measures (Article 5). There are some instances of business engagement in providing access to water and sanitation (CESCR General Comment No. 15). The link I establish here, of course, signifies the actions of the companies from the international water law perspectives. However, one needs to have quite a colorful imagination to attribute the reported shifts in the actions of the companies to the influence of international water law.

\section{Hopes to Become New Challenges?}

From the perspectives of the conceptual and empirical observations of this paper, the academic debate on institutional innovation appears to be focused predominantly on the introduction of new forms and new actors of governance. There seems to be considerable room to look beyond the mere value of institutional rearrangements and involvement of non-state actors, embracing also the mechanisms and paths that will, in effect, close the gaps in global governance.

Despite observable articulations themselves with identical conceptual narratives, the UN Global Compact and the UN multilateral regimes differ in actors, follow-up procedures and outputs. The UN Global Compact addresses private actors directly by involving them in the platform and translating for them the principles of multilateral regimes. It verifies the participant's compliance with its principles through the procedure of communication of progress resulting in COP reports (at times sustainability reports of the companies). This mostly separate initiative has a considerable potential of informing respective multilateral regimes about the progressive and regressive business practices within states. However, at this stage of the game they coexist as two parallel realties, one private-centric and the other state-centric.

The innovative institutional changes that only coexist with traditional multilateralism and share some conceptual narratives, may, in fact, deepen rather than close the governance gaps. Doubtless, making business familiar with conceptual attitudes of water management eventually contributes to improvements of business practices. Different claims can be made about the relevance of the reported activities of the private actors under the UN Global Compact for the multilateral water governance regimes, nonetheless on the operational level these two remain worlds apart. This, in my view, limits the use of the UN Global Compact's capacity as learning platform and does make the multilateral water regimes more susceptible to the actor unanimity.

of All Kinds of Discrimination Against Women), the Basel Convention on the Control of Transboundary Movements of Hazardous Wastes and their Disposal (United Nations, Treaty Series, vol. 1673, p. 57.), the UN Framework Convention on Climate Change (United Nations, Treaty Series, vol. 1771, p. 107) and its Kyoto Protocol (United Nations, Treaty Series, vol. 2303, p. 162.), the Paris Agreement (UN Treaty Depositary, Chapter XXVII Environment 7. d, 2015), Ramsar Convention (UN Treaty Series No. 14583, 1971), Convention concerning Indigenous and Tribal Peoples in Independent Countries (ILO, No. 169, 76th ILC session, 1989)) as well as the Universal Declaration of Human Rights (UN General Assembly resolution 217 A, 1948), the Rio Declaration on Environment and Development (UN Doc. A/CONF.151/26 (Vol. I); 31 ILM 874, 1992) and the Convention on Biological Diversity's Business and Biodiversity Pledge (Retrieved at https://www.cbd.int/business/pledges.shtml). 


\section{Concluding Remarks}

Every institutional innovation in global governance that makes non-state actors more involved with international law is vital for the multilateral regimes and for the best use of their capacities to drive progress. Doubtless, the UN Global Compact is among such innovations.

In this paper, I looked at the UN Global Compact not just as a stand-alone innovation but in its interdependence and interconnection with multilateral regimes of water governance. It is a questionable perspective. Nevertheless, it allows to extend our view beyond its role as an institutional innovation for involvement of non-state actors. The latter view dominates the academic discourse, which, in my understanding, has more to say not only about the necessity of institutional changes (also through involvement of non-state actors) but also about the shifts that such innovations bring into already functioning multilateral regimes (the actual closure of governance gaps).

To fulfill its objectives the UN Global Compact relies on and translates into business-friendly language the principles and the normative pillars of multilateral regimes of water governance. On the other side, some requirements of multilateral regimes that appear on the surface to address states can be enforced only when readdressed to non-state actors.

This apparent interdependence and relevance on a conceptual level is not reinforced on the operational level. The empirical analysis reveals businesses' engagement in a wide variety of actions that claim to reduce water consumption and to mitigate impacts on water resources. In other words, businesses claim to implement some of the requirements of multilateral water governance regimes and to promote, in some places, the human right to water and sanitation. However, the differences in actors, processes, outputs and the absence of communication make the achievements of non-state actors claimed under the UN Global Compact unverifiable against the requirements of multilateral regimes. Unverifiable, they become somewhat less meaningful for the recurrent governance issues of multilateralism.

The above picture is at odds with the innovative outlook of the UN Global Compact. Ironically the mutual reluctance of the state-centric regimes and the private-centric platform might even deepen the governance gaps rather than close them. The entire experience is very much reminiscent of the abyss emerging between partners in a passionate marriage constructed on poor strategies.

Funding: This research received no external funding.

Conflicts of Interest: The author declares no conflict of interest.

\section{References}

Aaronson, Susan Ariel, and Ian Higham. 2013. ‘Re-Righting Business': John Ruggie and the Struggle to Develop International Human Rights Standards for Transnational Firms. Human Rights Quarterly 35: 264-333. [CrossRef]

Abbott, Kenneth W., and Duncan Snidal. 2010. International Regulation without International Government: Improving IO Performance through Orchestration. The Review of International Organizations 5: 315-44. [CrossRef]

Abbott, Kenneth W., Jessica F. Green, and Robert O. Keohane. 2016. Organizational Ecology and Institutional Change in Global Governance. International Organization 70: 247-77. [CrossRef]

Andonova, Liliana B. Governance Entrepreneurs: International Organizations and the Rise of Global Public-Private Partnerships. Cambridge: Cambridge University Press.

Bäckstrand, Karin. 2006. Multi-Stakeholder Partnerships for Sustainable Development: Rethinking Legitimacy, Accountability and Effectiveness. European Environment 16: 290-306. [CrossRef]

Boisson de Chazournes, Laurence, Christina Leb, and Mara Tignino. 2011. Environmental Protection and Access to Water: The Challenges Ahead. In The Right to Water and Water Rights in a Changing World. Edited by Michael van der Valk and Penelope Keenan. Delft: UNESCO-IHE.

Caponera, Dante A. 1985. Patterns of Cooperation in International Water Law: Principles and Institutions. Natural Resources Journal 25: 563-87.

Caponera, Dante Augusto. 2003. National and International Water Law and Administration: Selected Writings. International and National Water Law and Policy Series; The Hague: Kluwer Law International. 
Conca, Ken. 2006. Governing Water: Contentious Transnational Politics and Global Institution Building. Cambridge: MIT Press.

Dellapenna, Joseph, and Joyeeta Gupta. 2008. Toward Global Law on Water. Global Governance 14: 442-43.

Drache, Daniel. 2001. The Market or the Public Domain?: Global Governance and the Asymmetry of Power. London: Routledge.

Fisher, Douglas E. 2009. The Law and Governance of Water Resources: The Challenge of Sustainability. New Horizons in Environmental and Energy Law Series; Cheltenham: Edward Elgar, p. 121.

Kell, Georg. 2003. The Global Compact: Origins, Operations, Progress, Challenges. The Journal of Corporate Citizenship 11: 35-49. [CrossRef]

Kell, Georg. 2005. The Global Compact Selected Experiences and Reflections. Journal of Business Ethics 59: 69-79. [CrossRef]

Kell, Georg, and John Gerard Ruggie. 1999. Global Markets and Social Legitimacy: The Case of the 'Global Compact'. Transnational Corporation 8: 101-20.

Lau, Cubie L.L., John F. Hulpke, William Aidan Kelly, and Susanna Taylor. 2017. United Nations Global Compact: The Unmet Promise of the UNGC. Social Responsibility Journal 13: 48-61. [CrossRef]

Ménard, Claude, and Peeroo Aleksandra. 2011. Liberalization in the Water Sector: Three Leading Models. In Rolf Kunneke and Matthias Finger. International Handbook of Network Industries: The Liberalization of Infrastrcutures. Cheltenham: Edward Elgar Publishing.

Moynihan, Ruby Mahana. 2018. Contribution of the UNECE Water Regime to International Law on Transboundary Watercourses and Freshwater Ecosystems. July 4. Available online: https:/ /www.era.lib.ed.ac.uk/handle/ 1842/31049 (accessed on 1 November 2018).

Rasche, Andreas, and Georg Kell. 2010. The United Nations Global Compact: Achievements, Trends and Challenges. Cambridge: Cambridge University Press.

Rasche, Andreas, Sandra Waddock, and Malcolm Mcintosh. The United Nations Global Compact: Retrospect and Prospect. Business and Society 52: 6-30. [CrossRef]

Ruggie, John G., ed. 2008. Embedding Global Markets: An Enduring Challenge. London: Routledge, p. 233.

Salman, M. A. Salman, and Siobhán McInerney-Lankford. 2004. The Human Right to Water. Legal and Policy Dimensions, World Bank, Law, Justice and Development Series; Washington, DC: World Bank, p. 81.

Scherer, Andreas Georg, and Guido Palazzo. 2011. The New Political Role of Business in a Globalized World: A Review of a New Perspective on CSR and Its Implications for the Firm, Governance and Democracy. Journal of Management Studies 48: 899-931. [CrossRef]

The CEO Water Mandate. 2014. Corporate Water Disclosure Guidelines toward a Common Approach to Reporting Water Issues. Oakland, CA: Pacific Institute, Available online: https:/ / ceowatermandate.org/files/Disclosure2014. pdf (accessed on 1 November 2018).

The CEO Water Mandate. 2015. Guidance on Respecting Human Rights to Water and Sanitation: Bringing a Human Rights Lens to Corporate Water Stewardship. Oakland, CA: Pacific Institute, Available online: http:/ / pacinst.org/wp-content/uploads/2015/01/Guidance-on-Business-Respect-for-the-HRWS.pdf (accessed on 1 November 2018).

Williams, Oliver F. 2007. The UN Global Compact: The Challenge and the Promise. In Corporate Ethics and Corporate Governance. Edited by Walther Ch Zimmerli, Markus Holzinger and Klaus Richter. Berlin and Heidelberg: Springer, p. 287.

(c) 2018 by the author. Licensee MDPI, Basel, Switzerland. This article is an open access article distributed under the terms and conditions of the Creative Commons Attribution (CC BY) license (http://creativecommons.org/licenses/by/4.0/). 